\title{
PEMBERDAYAAN KELUARGA DALAM PENCEGAHAN DAN PENANGANAN AWAL PENYAKIT DIARE PADA BAYI DAN BALITA DI AMPENAN KOTA MATARAM
}

\author{
Haryani, Melati Inayati Albayani, Zuliardi Musleh, Kusniyati Utami, \\ Marthilda Suprayitna \\ STIKes Yarsi Mataram \\ haryani444@gmail.com
}

\begin{abstract}
Diarrhea disease is still the main cause of death in the world. Almost all age groups are affected by diarrhea, especially children under five years because they do not have a maximum immune system or an immune system that is not fully awake (Sukardi \& Iskandar, 2005). Health behavior can be translated into a clean and healthy lifestyle that must start from the smallest unit of society, namely the behavior of living clean and healthy at home as an effort to empower household members to know, want and be able to practice clean and healthy living habits as a prevention of diarrhea. Knowledge of diarrheal diseases, knowledge of prevention of diarrheal diseases and early handling and danger signs of diarrhea. Methods: (i) Identification of the number of families targeted by Posyandu (ii) Socialization, and (iii) Evaluation. Result: The number of families that participated in community service activities was 20 people. From the evaluation of the activity, it was found that the family had understood about the prevention of diarrhea disease and its initial handling and how to make a salt sugar solution. Conclusion: The benefits of having knowledge and understanding about Diarrhea and its prevention are very helpful in efforts to improve the health of babies and children.
\end{abstract}

Keywords: Diarrhea, prevention and manufacture of $L G G$

\section{ABSTRAK}

Penyakit diare sampai saat ini masih menjadi penyebab utama dari kematian terbesar didunia. Hampir seluruh kelompok usia terserang diare khususnya paling banyak menyerang anak berusia di bawah lima tahun karena masih belum mempunyai daya tahan tubuh yang maksimal atau belum mempunyai sistem imun yang belum sepenuhnya terjaga (Sukardi \& Iskandar, 2005). Perilaku kesehatan dapat diwujutkan dengan perilaku hidup bersih dan sehat harus dimulai dari unit terkecil masyarakat yaitu perilaku hidup bersih dan sehat dirumah tangga sebagai upaya untuk memberdayakan anggota rumah tangga agar tahu, mau dan mampu memperaktikkan perilaku hidup bersih dan sehat sebagai pencegahan terjadinya diare. Tujuan: Pengetahuan tentang penyakit diare, Pengetahuan tentang pencegahan penyakit diare dan penanganan awal serta tanda bahaya penyakit diare. Metode: (i) Identifikasi jumlah keluarga yang menjadi sasaran Posyandu (ii) Sosialisasi, dan (iii) Evaluasi. Hasil: Jumlah keluarga yang mengikuti kegiatan pengabdian kepada masyarakat sebanyak 20 orang. Dari evaluasi kegiatan diperoleh keluarga telah memahami tentang pencegah penyakit diare dan penanganan awalnya serta cara pembuatan larutan gula garam. Kesimpulan: Manfaat dari adanya pengetahuan dan pemahaman tentang penyakit Diare dan pencegahannya sangat membantu di dalam upaya untuk meningkatkan kesehatan bayi dan anak.

Kata kunci: Penyakit Diare, pencegahan dan pembuatan LGG

Submitted: 2020-09-18 Revised: $2020-10-19$ Accepted: $2020-10-21$ 


\section{Pendahuluan}

Diare didapat dikatakan sebagai masalah pediatric sosial karena diare merupakan salah satu penyakit utama yang terdapat dinegara berkemang, dimana adanya faktor yang mempengaruhi terjadinya diare pada balita itu sendiri yaitu diantaranya faktor penyebab (agent), penjamu (host), dan faktor lingkungann (environment) (Suharyo, 2008).Menurut Fenioktaviani (2010) penyebab tingginya kejadian diare kemungkinan besar disebabkan oleh adanya berbagi macam faktor resiko kemungkinan besar disebabkan oleh adanya berbagai macam faktor resiko penyakit diare antara lain kondisi sanitasi lingkungann yang kurang baik, hygine perorangan yang kurang baik, sanitasi makanan yang kurang baik, masalah nutrisi dan imunitas tubuh, pemberian ASI eksklusif yang rendah, pemberian makanan tambahan terlalu dini, dan stress yang berlebihan.

Angka kejadian penyakit diare dapat diturunkan dan komplikasi dapat dicegah dengan peningkatan pengetahuan masyarakat akan penyakit diare dan adanya upaya pencegahan dimana salah satunya dengan perubahan perilaku hidup sehat. Perilaku kesehatan dapat diwujutkan dengan perilaku hidup bersih dan sehat harus dimulai dari unit terkecil masyarakat yaitu perilaku hidup bersih dan sehat dirumah tangga sebagai upaya untuk memberdayakan anggota rumah tangga agar tahu, mau dan mampu memperaktikkan perilaku hidup bersih dan sehat sebagai pencegahan terjadinya diare. Penerapan perilaku hidup bersih dan sehat pada balita tergantung kepada perilaku hidup bersih dan sehat ibu, karena balita masih tidak bisa melakukan segala sesuatu dengan sendiri (Departemen Kesehatan RI, 2011).

Di Lingkungan Tempit sedikit dari mereka yang memahami tentang penyakit diare dan arti pentingnya perilaku hidup bersih dan sehat(PHBS) guna mencegah terjadinya diare dan menurunkan angka kesakitan akibat. Berdasarkan uraian diatas tim pengabdian kepada masyarakat melaksanakan sosialisasi mengenai pencegahan dan penanganan awal penyakit diare Lingkungan Tempit, Ampenen Kota Mataram

\section{Metode}

Kegiatan pada pengabdian kepada masyarakat "'Pemberdayaan masyarakat dan keluarga dalam pencegahan dan penanganan awal penyakit diare di Ampenan Kota Mataram" yaitu (i) Identifikasi jumlah bayi dan balita (ii) Sosialisasi, dan (iii) Evaluasi.

1. Identifikasi jumlah bayi dan balita

Identifikasi jumlah bayi dan balita dimulai dari mengidentifikasi jumlah bayi dan balita dan jumlah bayi dan balita yang pernah atau tidak pernah menderita penyakit diare.

2. Sosialisasi

Materi sosialisasi terdiri dari Penyakit diare, Pencegahan dan penanganan awal penyakit diare. Adapun materi sosialisasi Penyakit diare, Pencegahan dan penanganan awal penyakit diare adalah sebagai berikut:

a. Pengertian Penyakit diare

b. Penyebab penyakit diare

c. Tanda dan gejala penyakit diare

Materi sosialisasi adalah pencegahan penyakit diare dan penanganan awal serta tanda bahaya penyakit diare sebagai berikut: 

a. Pencegahan penyakit diare
b. Penanganan awal penyakit diare
c. Tanda bahaya penyakit diare
d. Tindakan yang harus dilakukan jika anak sakit diare

3. Evaluasi

Evaluasi dilakukan saat pertemuan terakhir dengan mengevaluasi pengetahuan Pemberdayaan masyarakat dan keluarga dalam pencegahan dan penanganan awal penyakit diare di Ampenan Kota Mataram. Hasil evaluasi ditindaklanjuti dengan evaluasi kejadian diare pada bayi dan balita dan keadaan tempat tinggal dan lingkungann sekitar masyarakat.

Kegiatan pada pengabdian kepada masyarakat "Pemberdayaan masyarakat dan keluarga dalam pencegahan dan penanganan awal penyakit diare pada bayi dan balita di Lingkungan Tempit Kelurahan Ampenan Tengah, Ampenan Kota Mataram" ini tidak lepas dari partisipasi mitra yang diantaranya yaitu:

a. Memberikan ijin pelaksanaan kegiatan

b. Menyiapkan evaluasi secara bersama

Kegiatan pada pengabdian kepada masyarakat "'Pemberdayaan masyarakat dan keluarga dalam pencegahan dan penanganan awal penyakit diare di Ampenan Kota Mataram" yaitu (i) Identifikasi jumlah bayi dan balita (ii) Sosialisasi, dan (iii) Evaluasi.

1. Identifikasi jumlah bayi dan balita

Identifikasi jumlah bayi dan balita dimulai dari mengidentifikasi jumlah bayi dan balita dan jumlah bayi dan balita yang pernah atau tidak pernah menderita penyakit diare.

2. Sosialisasi

Materi sosialisasi terdiri dari Penyakit diare, Pencegahan dan penanganan awal penyakit diare. Adapun materi sosialisasi Penyakit diare, Pencegahan dan penanganan awal penyakit diare adalah sebagai berikut:
a. Pengertian Penyakit diare
b. Penyebab penyakit diare
c. Tanda dan gejala penyakit diare

Materi sosialisasi adalah pencegahan penyakit diare dan penanganan awal serta tanda bahaya penyakit diare sebagai berikut:
a. Pencegahan penyakit diare
b. Penanganan awal penyakit diare
c. Tanda bahaya penyakit diare
d. Tindakan yang harus dilakukan jika anak sakit diare

3. Evaluasi

Evaluasi dilakukan saat pertemuan terakhir dengan mengevaluasi pengetahuan Pemberdayaan masyarakat dan keluarga dalam pencegahan dan penanganan awal penyakit diare di Ampenan Kota Mataram. Hasil evaluasi ditindaklanjuti dengan evaluasi kejadian diare pada bayi dan balita dan keadaan tempat tinggal dan lingkungann sekitar masyarakat.

Kegiatan pada pengabdian kepada masyarakat "Pemberdayaan masyarakat dan keluarga dalam pencegahan dan penanganan awal penyakit diare pada bayi dan balita 
di Lingkungan Tempit Kelurahan ampnen Tengah, Ampenan Kota Mataram" ini tidak lepas dari partisipasi mitra yang diantaranya yaitu:

a. Memberikan ijin pelaksanaan kegiatan

b. Menyiapkan evaluasi secara bersama

\section{Hasil dan Pembahasan}

Berdasarkan pengamatan kami selaku pelaksana dari kegiatan tersebut antusias masyarakat khususnya para ibu cukup tinggi untuk mengikuti kegiatan pengabdian, hal itu terbukti dari jumlah ibu atau keluarga yang mengikuti kegiatan tersebut yang berjumlah 20 orang berdasarkan laporan dari kepala lingkungan dan kader selaku pembantu penyelenggara kegiatan tersebut.

Kegiatan ini dilakukan secara bertahap yang dijelaskan secara rinci di bawah ini:

1. Identifikasi wanita usia subur

Peserta kegiatan pengabdian kepada masyarakat ini digambarkan pada tabel di bawah ini:

Tabel 1. Tabel hasil identifikasi wanita usia subur

\begin{tabular}{|c|c|c|}
\hline No & Inisial nama peserta & $\begin{array}{l}\text { Usia bayi/anak } \\
\text { saat ini (bulan) }\end{array}$ \\
\hline 1 & IN & 13 \\
\hline 2 & AN & 26 \\
\hline 3 & $\mathrm{KN}$ & 24 \\
\hline 4 & NT & 8 \\
\hline 5 & $\mathrm{HT}$ & 6 \\
\hline 6 & SU & 5 \\
\hline 7 & $M$ & 13 \\
\hline 8 & YS & 18 \\
\hline 9 & $\mathrm{JA}$ & 21 \\
\hline 10 & WR & 15 \\
\hline 11 & ST & 20 \\
\hline 12 & SI & 30 \\
\hline 13 & FA & 2 \\
\hline 14 & KS & 7 \\
\hline 15 & G & 15 \\
\hline 16 & $\mathrm{R}$ & 12 \\
\hline 17 & AT & 9 \\
\hline 18 & $\mathrm{BI}$ & 11 \\
\hline 19 & FG & 16 \\
\hline 20 & MI & 6 \\
\hline
\end{tabular}

2. Sosialisasi

Kegiatan sosialisasi ini dilakukan pada tanggal 11 April 2019 di Lingkungan Tempit Kelurahan Ampenan Tengah, Ampenan Kota Mataram. Sebelum melakukan kegiatan pengabdian kami melakukan wawancara terhadap beberapa ibu apakah mereka mengetahui dan memahami tentang pencegahan penyakit Diare khususnya tentang tanda bahaya yang terjadi pada bayi atau balita yang terkena ISPA, sebagian besar ibu-ibu menjawab "tidak tahu" tetapi mereka sering mendengar tentang 
penyakit sesak atau batuk. Istilah Diare memang mereka ada beberapa yang tahu dan sebagian besar dari mereka baru saja mendengar saat tim menyampaikan materinya.

Materi Penyakit Diare dan pencegahannya disampaikan dalam bentuk Power point dan Leaflet. Materi penyuluhan tentang penyakit Diare, pencegahannya dan penanganan awal diikuti dengan cukup khidmat oleh peserta, materi yang disampaikan cukup menarik perhatian para ibu untuk ingin diskusi tentang hal tersebut terlihat dari banyaknya ibu yang bertanya kepada Tim. Sebagai bentuk timbal balik dari penyampaian materi tersebut penyuluh memberika apresiasi berupa bingkisan. Para ibu mengungkapkan bahwa baru sekarang mengetahui dan menyadari tentang bahaya penyakit Diare dan ada beberapa dari mereka yang merasa bahwa jika anak masih bayi atau balita sering sakit batuk atau sesak adalah merupakan suatu hal yang biasa, bahkan beberapa dari mereka ada yang percaya(mitos) jika sakit yang dialami seorang bayi atau balita adalah merupakan tanda adanya suatu perubahan dalam tubuh bayi yang akan menjadi lebih baik.

3. Evaluasi

Kegiatan evaluasi dilakukan pada tanggal 15 Juni 2019 terdiri dari:

a. Evaluasi struktur

1) $80 \%$ atau lebih peserta menghadiri acara

2) Alat dan media sesuai dengan rencana

3) Peran dan fungsi masing-masing sesuai dengan yang direncanakan

b. Evaluasi proses

1) Pelaksanaan kegiatan sesuai dengan waktu yang direncanakan

2) Peserta penyuluhan mengikuti kegiatan dari awal sampai akhir

3) Peserta berperan aktif dalam jalannya diskusi

c. Evaluasi hasil

Setelah diberikan penyuluhan diharapkan peserta mampu:

1) Ibu/keluarga mampu menyebutkan pengertian penyakit Diare

2) Ibu/keluarga mampu menyebutkan penyebab penyakit Diare

3) Ibu/keluarga mampu menyebutkan Tanda dan gejala penyakit Diare

4) Ibu/keluarga mampu menyebutkan Cara pencegahan penyakit Diare

5) Ibu/keluarga mampu menyebutkan tanda bahaya pada penyakit Diare

6) Ibu/keluarga mampu menyebutkan cara penanganan awal jika bayi/balita Diare.

7) Ibu/keluarga mampu mampu menyebutkan hal yang dilakukan jika bayi dan balita menderita penyakit Diare.

\section{Kesimpulan}

Penyakit Diare merupakan salah satu penyakit yang sering dan mudah diderita oleh bayi dan, beberpa pencegahan dapat dilakukan dengan salah satunya melakukan menjaga kebersihan lingkungan, memperhatikan sirkulasi dan sanitasi di rumah dan lingkungan sekitar. Tanda bahaya dari Diare juga penting untuk diketahui agar dapat segera ditangani dengan seksama sehingga dapat menurunkan angka kesakita dan kematian pada bayi dan balita serta prognosis menjadi lebih baik. 
Manfaat dari adanya pengetahuan dan pemahaman tentang penyakit Diare dan pencegahannya sangat membantu di dalam upaya untuk meningkatkan kesehatan bayi dan anak tidakan yang sederhana, tepat dan cepat dapat dilakukan oleh keluarga dalam membantu mengurangi terjadinya penyakit dan menurunkan komplikasi akibat dari suatu penyakit serta memiliki kemampuan untuk mengambil keputusan yang benar dalam penanganan penyakit yang diderita oleh bayi atau anak serta keluarga.

\section{Daftar Pustaka}

Anne, Ahira. (2008).Epidemiologi Diare: Karena Lingkungan yang Kotor. http//anne ahira.com

Departemen Kesehatan RI. (2011). Diare Akut. Buku Ajar Diare. Jakarta: Depkes RI.

Depkes, R. I. (2018) Pedoman Pemberantasan Penyakit Diare. Jakarta: Ditjen Ppm Dan PI; 2005

Hendra, AW. (2008), Faktor-faktor yang Mempengaruhi Pengetahuan, Jakarta, Pustaka Sinar harapan

Ngastiyah. (2015). Asuhan Keperawatan Penyakit Anak Edisi 3. Jakarta: EGC.

Soegiyanto,(2012). Ilmu Penyakit Anak: Diagnose dan penatalaksanaan, Edisi Pertama, Jakarta, Salemba Medika

Soebagyo, B. (2008) Diare Akut Pada Anak. Surakarta: Universitas Sebelas Maret Press.

Suharyono. (2008). Diare Akut. Jakarta; Rineka Cipta

Wawan dan Dewi, (2010), Teori dan Pengukuran Pengetahuan, Sikap Dan Perilaku Manusia, Yogyakarta: Nuha Medika

World Healt Organization (WHO). (2012). Global Water Supply And Sanitation Assesment. World Healt Organization. 